\title{
STRUCTURAL AND ELECTROCHEMICAL PROPERTIES OF CHEMICALLY DEPOSITED COPPER DOPED NICKEL HYDROXIDE
}

KEY WORDS:CBD, marigold, microflower, supercapacitor, nickel hydroxide.
D.B. Mane*

L.D. Kadam

\section{R.V. Dhekale}

\section{G. M. Lohar}

Department of Physics, Lal Bahadur Shastri College of Arts, Science And Commerce, Satara 415002. *Corresponding Author Department of Physics, Arts, Commerce And Science College, Ramanadnagar (Burli) 416308

Department of Physics, Kisan Veer Mahavidyalaya, Wai 412803

Department of Physics, Lal Bahadur Shastri College of Arts, Science And Commerce, Satara 415002

단 Present work reported, copper doped $\mathrm{Ni}(\mathrm{OH})_{2}$ deposited successfully by chemical bath deposition method on 0 economical stainless steel electrode. The XRD analysis represent hexagonal crystal structure and presence of $\mathrm{Ni}$ and $\mathrm{Cu}$ confirm by FT-IR study.The surface morphology studied by SEM indicates nanopetals linked marigold like microflowers. The $0.2 \% \mathrm{Cu}$ doped $\mathrm{Ni}(\mathrm{OH}) 2$ shows specific capacitance $715 \mathrm{Fg}^{-1}$ at scan rate $10 \mathrm{mV} \mathrm{s}^{-1}$. EIS study interprets that electrode N- $0.2 \%$ have least charge transfer resistance which improve value of specific capacitance. All results revels cupper is good dopant for improve the specific capacitance.

\section{INTRODUCTION}

Conventional energy sources like coal, mineral oils and natural gas have many fatal issues regarding to health and environment. Pollution, global warming, greenhouse effect, diseases related air are serious problems caused by combustion of non-renewable energy sources. These sources of energy are limited. Solar energy, wind energy, ocean energy are nonconventional energy sources possess some advantages and some drawbacks like availability, affected by atmospheric condition[1,2]. It urgent to search for a energy storage device which have high power density, cyclic stability and high specific capacitance. Supercapacitor is better option for these search. Recently many researcher work on electrode material and transition metal oxides and hydroxide give impressive results. Ruthenium oxide, cobalt oxide, iron oxide, vanadium oxide, nickel oxide and nickel hydroxide are many transition metal oxide and hydroxide materials are used in supercapacitor[3][4].Nickel hydroxide used as in nickel hybrid batteries ,in fuel cell and in many electrochemical sensor. $\mathrm{Ni}(\mathrm{OH}) 2$ have high theoretical specific capacitance $2055 \mathrm{~F} \mathrm{g-1} \mathrm{and} \mathrm{cheap[5].} \mathrm{Electrochemical} \mathrm{properties} \mathrm{of}$ material depends on morphology and Many type of morphology observed by $\mathrm{Ni}(\mathrm{OH}) 2$ material. These different nanostructure produced by simple chemical methods [6].

Lokhande et al. synthesise $\mathrm{Ni}(\mathrm{OH}) 2$ microflower successfully with higher specific capacitance $562 \mathrm{~F} \mathrm{g-l}$ at scan rate $10 \mathrm{mV}$ s-1.They also archives $\alpha$ phase of $\mathrm{Ni}(\mathrm{OH}) 2$ [7].Liu et al.reported 3D self-assemble porous structure have higher specific capacitance $2110 \mathrm{~F} \mathrm{g-l}$ for current density 1 A g-l can deposited by CBD method[8]. Doping of transition elements improve electrochemical properties of supercapacitor. Liu et al. doped cobalt in $\mathrm{Ni}(\mathrm{OH}) 2$ improve specific capacitance $2879 \mathrm{Fg}-1$ at current density $1 \mathrm{Ag}-1$.They also reported doping majorly affected by size of element and electronegativity majorly affect[9].

\section{EXPERIMENTAL}

The copper doped nickel hydroxide thin films were deposited by chemical bath deposition method by on costeffective stainless-steel substrate as a current collector. IM $\mathrm{NiSO}_{4} 6 \mathrm{H}_{2} \mathrm{O}$ and $1 \mathrm{M} \mathrm{CuSO}_{4} 6 \mathrm{H}_{2} \mathrm{O}$ was used as nickel source and copper source in double distilled water (DDW). The different concentration of $(0.1 \%, 0.2 \%$ and $0.3 \%) \mathrm{CuSO}_{4} 6 \mathrm{H}_{2} \mathrm{O}$ was added into $1 \mathrm{M} \mathrm{NiSO}_{4} 6 \mathrm{H}_{2} \mathrm{O}$ with constant stirring in a beaker. $0.25 \mathrm{M} \mathrm{K}_{2} \mathrm{~S}_{2} \mathrm{O}_{8}$ and aq. $\mathrm{NH}_{3}$ was added into the solution. The precleaned substrates were dipped in the above beaker and kept at room temperature for $2 \mathrm{~h}$. After that substrate heated at temp $100^{\circ} \mathrm{C}$ for $2 \mathrm{hr}$. For $0.1 \%, 0.2 \%$ and $0.3 \% \mathrm{Cu}$ doping the obtained films were named as $\mathrm{N}-0.1 \%, \mathrm{~N}-0.2 \%$ and $\mathrm{N}-0.3 \%$ respectively.

\section{RESULT AND DISCUSSION}

\section{STRUCTURAL AND MORPHOLOGICAL PROPERTIES}

$\mathrm{X}$-ray diffraction analysis and FT-IR study are used to determine structural properties of electrode.
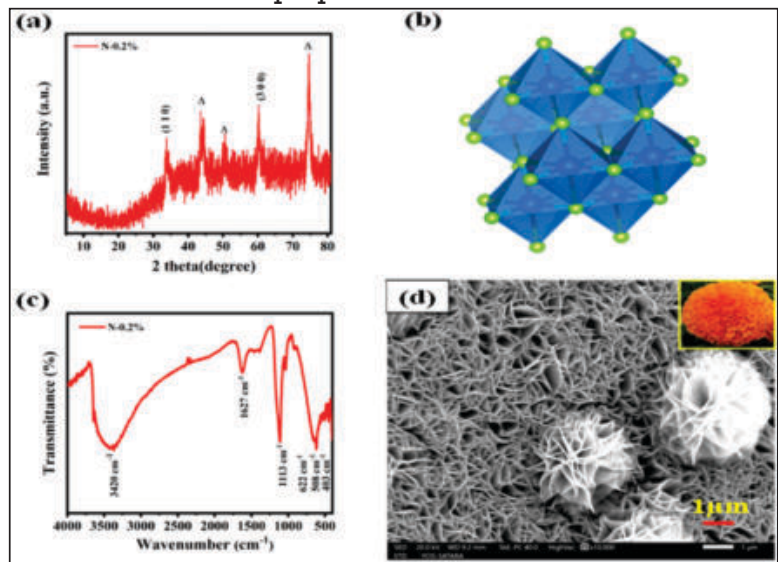

Fig. 1 a represent XRD pattern of $\mathrm{N}-0.2 \%$ optimize electrode. Spectrum shows peaks at 33.81 and $60.24^{\circ}$ corresponding to (l 110$)$ and (3 0 0) plane. $\mathrm{Ni}(\mathrm{OH}) 2$ XRD data matches with JCPDS card 022-0444 which indicate hexagonal crystal structure.

Fig. 1 (b) shows crystal structure of $\mathrm{Ni}(\mathrm{OH}) 2$. Lattice parameter are lattice parameter are $\mathrm{a}=\mathrm{b}=5.34 \mathrm{~A}^{\circ}, \mathrm{c}=7.5 \mathrm{~A}^{\circ}$ and $\boldsymbol{\alpha}=\boldsymbol{\beta}=90^{\circ},=120^{\circ}$.

Fig. 1 c shows FT-IR analysis of $\mathrm{N}-0.2 \%$ electrode. This analysis studied at range 400 to $4000 \mathrm{~cm}-1$ wavenumber. Peak at 508 $\mathrm{cm}^{-1}$ indicates presence of $\mathrm{Cu}(\mathrm{OH})_{2}$ and $403 \mathrm{~cm}^{-1}$ indicate $\mathrm{Ni}-\mathrm{O}$ stretching mode [10][11]. Presence of $\mathrm{O}-\mathrm{H}$ molecule represent by peak values of 3420 and $1627 \mathrm{~cm}^{-1}$. The $\mathrm{S}=\mathrm{O}$ bond represent by wavenumber $1113 \mathrm{~cm}^{-1}$.

Fig. 1 d shows SEM image of $\mathrm{N}-0.2 \%$ electrode. SEM image shows Marigold like flowers form on surface of electrode. This microstructure increases effective surface area so improvement of electrochemical properties occurs. 


\section{Electrochemical Properties And Electrochemical Impedance Spectroscopy}
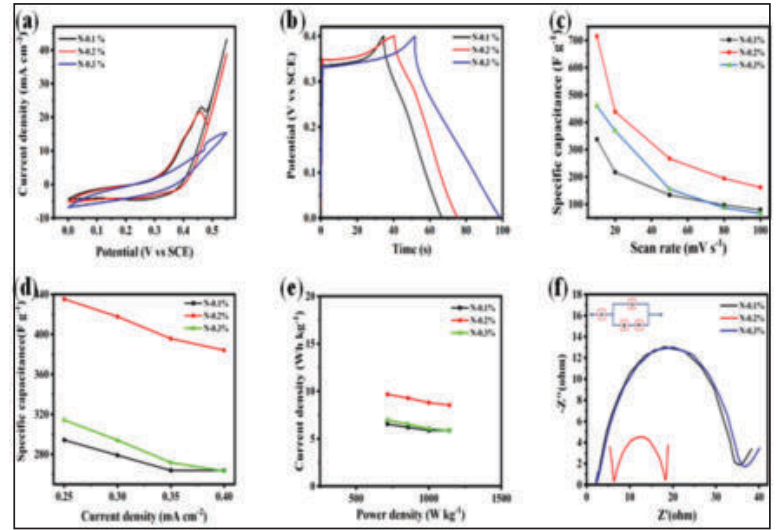

Fig. 2 Supercapacitor study of copper doped nickel hydroxide (a) Cyclic voltammograms of different electrode at scan rate $1 \mathrm{mV}$ s-l. (b)Galvanostatic charge-discharge study of different electrodes at current density $2.5 \mathrm{~mA} \mathrm{~cm}-2$. (c)Variation of scan rate vs. specific capacitance of different electrodes. (d)Current density vs. specific capacitance of different electrodes. (e)Rogene plot of different electrode. (f) Nyquist plot for different electrode.

Fig. 2 a indicate $\mathrm{CV}$ of $\mathrm{N}-0.1 \%, \mathrm{~N}-0.2 \%$ and $\mathrm{N}-0.3 \%$ electrode. Area under CV graph increases as scan rate increases which improve rate of interaction between electrode and electrolyte[12]. Specific capacitance calculated from CV are 338,715 and $360 \mathrm{Fg}-1$ at scan rate $10 \mathrm{mV} \mathrm{s}-1$.

Fig $2 \mathrm{~b}$ shows GCD of $\mathrm{N}-0.1 \%, \mathrm{~N}-0.2 \%$ and $\mathrm{N}-0.3 \%$ electrode. Electrode $\mathrm{N}-0.2 \%$ have maximum discharge time. Specific capacitance calculated from GCD are 314,435 and $230 \mathrm{Fg}-1$ at current density $2.5 \mathrm{~mA} \mathrm{~cm}-2$.

Fig 2 c shows Variation of scan rate vs. specific capacitance of different electrodes. Current density vs. specific capacitance of different electrodes shown in

fig 2 d. Rogene plot represented in fig 2 e. Fig 2 f shows Nyquist plot for different electrode. All electrode have approximately same solution resistance but electrode $\mathrm{N}$ $0.2 \%$ smaller charge transfer resistance. After the interpretation of electrochemical analysis, electrode $\mathrm{N}-0.2 \%$ have higher specific capacitance. Improved value of specific capacitance prove $\mathrm{Ni}^{+2}$ ions successfully replace by $\mathrm{Cu}^{+2}$ ions. Marigold like morphology increases effective surface area of electrode-electrolyte interaction so rate of faradic reaction increases which result increase in specific capacitance of electrode.

\section{CONCLUSIONS}

The copper doped $\mathrm{Ni}(\mathrm{OH})_{2}$ successfully deposited by chemical bath deposition method. The structural study reveals that $\mathrm{Ni}(\mathrm{OH})_{2}$ deposited with hexagonal crystal structure. FT-IR study confirm doping of copper in $\mathrm{Ni}(\mathrm{OH})_{2}$ with $\mathrm{Cu}-\mathrm{O}$ peak. The SEM study shows marigold flower like microstructure deposited on surface which improve electrochemical properties. After study of supercapacitive properties $0.2 \%$ doping copper in $\mathrm{Ni}(\mathrm{OH})_{2}$ electrode have greater specific capacitance $715 \mathrm{Fg}^{-1}$ for scan rate $10 \mathrm{mV} \mathrm{s}^{-1}$. Present work conclude that copper is good option for doping which is ecofriendly, cheap and easily deposited by chemical method.

\section{REFERENCES:}

[1] Vivek, C. M., Ramkumar, P., Srividhya, P. K. and Sivasubramanian, M. (2021) Recent strategies and trends in implanting of renewable energy sources for sustainability - A review. Materials Today: Proceedings, Elsevier 46, 8204-8208.

[2] Alsharif, A.,Tan, C.W., Ayop, R., Dobi, A. and Lau, K.Y. (2021) A comprehensive review of energy management strategy in Vehicle-to-Grid technology integrated with renewable energy sources. Sustainable Energy Technologies and Assessments, Elsevier 47, 101439.

[3] Zhang, G., Xiao, X. Li, B., Gu, P., Xue, H. and Pang, H. (2017) Transition metal oxides with one-dimensional/one-dimensional-analogue nanostructures for advanced supercapacitors. Journal of Materials Chemistry A, The Royal Society of Chemistry 5,8155-8186.

[4] Kate, R. S., Khalate, S. A. and Deokate, R. J. (2018) Overview of nanostructured metal oxides and pure nickel oxide $(\mathrm{NiO})$ electrodes for supercapacitors: $A$ review. Journal of Alloys and Compounds, Elsevier 734,89-11 1.

[5] Basirun, W. J., Saeed, I. M., Rahman, M. S. and Mazari, S. A. (2021) Nickel oxides/hydroxides-graphene as hybrid supercapattery nanocomposites for advanced charge storage materials - a review. https:// doi. org/ 10. 1080/ 10408436.2021.1886040, Taylor \& Francis 46,553-586.

[6] Sci-Hub || 10.1016/j.electacta.2020.137633.

[7] Lokhande, P. E., Pawar, K. and Chavan, U. S. (2018) Chemically deposited ultrathin $\alpha-\mathrm{Ni}(\mathrm{OH}) 2$ nanosheet using surfactant on $\mathrm{Ni}$ foam for high performance supercapacitor application. Materials Science for Energy Technologies, KeAi Communications Co. 1, 166-170.

[8] Liu, F., Chu, X., Zhang, H., Zhang, B., Su, H., Jin, L., Wang, Z., Huang, H. and Yang, W. (2018) Synthesis of self-assembly 3D porous $\mathrm{Ni}(\mathrm{OH}) 2$ with high capacitance for hybrid supercapacitors. Electrochimica Acta, Elsevier Ltd 269, 102-110.

[9] Liu, L., Hou, Y., Gao, Y., Yang, N., Liu, J. and Wang, X. (2019) Co doped $\square-\mathrm{Ni}(\mathrm{OH}) 2$ multiple-dimensional structure electrode material. Electrochimica Acta, Elsevier Ltd 295, 340-346.

[10] Naveenkumar, P., Paruthimal Kalaignan, G., Arulmani, S. and Anandan, S. (2018) Solvothermal synthesis of $\mathrm{CuS} / \mathrm{Cu}(\mathrm{OH}) 2$ nanocomposite electrode materials for supercapacitor applications. Journal of Materials Science: Materials in Electronics, Springer New York LLC 29, 16853-16863.

[11] Kalam, A., Al-Sehemi, A. G., Al-Shihri, A. S., Du, G. and Ahmad, T. (2012) Synthesis and characterization of NiO nanoparticles by thermal decomposition of nickel linoleate and their optical properties. Materials Characterization 68,77-81.

[12] Pore, O.C..Fulari, A.V.,Velha, N. B.,Parale,V.G.,Park, H.H., Shejwal, R.V.,Fulari, V. J. and Lohar, G. M. (2021) Hydrothermally synthesized urchinlike NiO nanostructures for supercapacitor and nonenzymatic glucose biosensing application. Materials Science in Semiconductor Processing, Pergamon 134 105980. 